\title{
ASSIGNMENTS AND TRANSFERS OF CONTRACTUAL DUTIES: INTEGRATING THEORY AND PRACTICE
}

\author{
Justine Kirby*
}

While contractual rights are usually assignable, the extent to which contractual obligations may be "assigned" or otherwise "transferred" is unclear. In this article, Justine Kirby examines the common law, section 11 of the Contractual Remedies Act 1979, and accepted methods of "transferring" obligations, and then compares the effects of a purported assignment of obligations under New Zealand, English and United States law. She argues that the law should be clarified, and offers drafting suggestions to lawyers to give effect to parties' intentions while the law remains uncertain.

\section{INTRODUCTION}

Commercial lawyers deal with the transfer of contracts, contractual rights and contractual obligations as a matter of course. Yet the law on the assignment or transfer of contractual obligations is far from clear - due to issues arising at common law, under statutory provisions and from the drafting of assignment provisions and related documents.

In Part II, this article examines the assignment of contractual obligations at common law, the effect of section 11 of the Contractual Remedies Act 1979, and specific statutory transfers, and in Part III, sets out accepted methods of "transferring" obligations. In Part $\mathrm{IV}$, it then analyses the purported assignment of obligations by comparing the New Zealand, English and United States law and Part V focusses specifically on contractual provisions purporting to enable a party to transfer contractual obligations in the future. Finally, Part VI offers drafting suggestions to parties wishing to transfer contractual obligations (or to retain the right to do so in future).

LLB(Hons) B Com (Canterbury), LLM (Harvard); Associate, Debevoise \& Plimpton, New York. This article was written while the author was a Senior Solicitor at Chapman Tripp, Wellington. 


\section{ASSIGNORS CAN ASSIGN ONLY CONTRACTUAL RIGHTS}

\section{A General Principle}

In contract law, an assignment involves an "assignor" transferring ${ }^{1}$ some or all of its rights under a contract to an "assignee", so that the assignee is entitled to the corresponding performance directly from, and can enforce those rights against, ${ }^{2}$ the nonassigning party. ${ }^{3}$ An assignment in itself does not create a contract between the assignee and the non-assigning party nor does it make the assignee a party to the original contract. ${ }^{4}$ Shown diagrammatically: 5

1 This article does not discuss the methods of assignment under s 130(1) of the Property Law Act 1952 or in equity.

2 The assignee's right to seek remedies from the non-assigning party is subject to the terms of the contract between the assignor and non-assigning party: s 11(1) of the Contractual Remedies Act 1979.

3 The assignor and assignee usually do not need the non-assigning party's consent to the assignment (unless, for example, the contract prohibits the assignment of rights without consent, or the rights and corresponding obligations are of such a personal nature that the parties' intention is that the rights are not assignable such as in Kemp v Baerselman [1906] 2 KB 604 (CA)).

4 Gibbston Valley Estate Limited v Owen (2 June 1999) unreported, Court of Appeal, CA 175/98, 8; (1999) 4 NZ Com 193,024 [Gibbston Valley]. The elements needed for a contract between the assignee and non-assigning party do not exist (for example there is no meeting of the minds of the assignee and non-assigning party, and no consideration).

5 The diagrams in this article use unbroken lines for contractual rights/obligations and broken lines for other matters. 
The general principle is that while a party may usually assign its contractual rights (or "benefits") it may not assign its contractual obligations (or "burdens", "duties" or "liabilities") - and hence, while that party has unperformed obligations, it cannot assign a contract as a whole. ${ }^{6}$ This protects the interests of the non-assigning party: ${ }^{7}$

[a]ny one who is bound to any performance whatever or who owes money cannot by any act of his own, or by any act in agreement with any other person than his creditor or the one to whom his performance is due, cast off his own liability and substitute another's liability. If this were not true, obligors could free themselves of their obligations by the simple expedient of assigning them.

And: 8

... A cannot without the consent of B assign the burden of the contract to C, because B has contracted for performance by $\mathrm{A}$ and he cannot be required against his will to accept performance by $\mathrm{C}$ or anyone other than $\mathrm{A}$.

The general principle also protects the assignee, by preventing the assignor from imposing contractual obligations on the assignee without the assignee's consent. ${ }^{9}$

Despite this general principle, commercial lawyers often refer to assigning "a contract". In Linden Gardens Trust Limited v Lenesta Sludge Disposals Limited Lord Browne-Wilkinson explained this as follows: ${ }^{10}$

6 See "Obligations of the Assignee of a Bilateral Contract" (1929) 42 Harv L Rev 941 ["Bilateral Contract"] (a contract cannot be assigned as it is only a promise creating legal rights and obligations, with only the right created by the promise being assignable).

7 Crane Ice Cream Co v Terminal Freezing \& Heating Co (1925) 128 A 280, 283. In particular, a party could otherwise transfer its obligations to obliging insolvents: Farnsworth on Contracts (Little, Brown and Company, Boston, 1990) volume III, 126-127 [Farnsworth]. C L Knapp \& N M Crystal Problems in Contract Law (2 ed, Little, Brown and Company, Boston, 1987) 1133 state, somewhat colourfully, that "[i]f assigning a right is like passing a football, then delegating a duty resembles more the dissemination of a catchy tune or a contagious disease. Passing it on is not the same as getting rid of it".

8 Southway Group Limited v Wolff (1991) 57 BLR 33, 52 (CA) [Southway Group]. Similarly J Chitty and A G Guest (eds) Chitty on Contracts - General Principles (27 ed, Sweet \& Maxwell, London, 1994) 985.

9 M P Furmston "The Assignment of Contractual Burdens" (1998) 13 Journal of Contract Law 42.

10 Linden Gardens Trust Limited v Lenesta Sludge Disposals Limited [1994] 1 AC 85, 103 (HL). Also, in the Court of Appeal Staughton LJ noted that "assign" is often used incorrectly in relation to vicarious performance: Linden Gardens Trust Limited v Lenesta Sludge Disposals Limited (1992) 57 BLR 66, 82 (CA). 
Although it is true that the phrase "assign this contract" is not strictly accurate, lawyers frequently use those words inaccurately to describe an assignment of the benefit of a contract since every lawyer knows that the burden of a contract cannot be assigned.

It is not only lawyers who refer to assigning contracts as a whole (or both the rights and obligations under contracts): recent New Zealand Court of Appeal judgments also refer to assigning obligations. ${ }^{11}$

Similar terminology issues arise in the United States, with a leading text lamenting that references to assignment of a "contract" make discussion "much confused" and calling for precision as to whether a proposed transfer is of a contractual right, obligation or both. ${ }^{12}$

\section{B Common Law Qualifications}

Even at common law, ${ }^{13}$ there are various qualifications to the general principle that contractual obligations are not assignable.

An assignee takes rights "subject to equities". ${ }^{14}$ In Tito $v$ Waddell (No 2) Megarry V-C, referring to one aspect of this principle, stated that an assignee may obtain "a conditional or qualified right, the condition or qualification being that certain restrictions shall be observed or certain burdens assumed, such as an obligation to make certain payments" which are "an intrinsic part of the right". ${ }^{15}$ More recently, in Rhone $v$ Stephens Lord

11 See below Part II, C1.

12 S Willisten and W Jaegar Williston on Contracts ( 3 ed, Baker, Voorhis \& Co, Mount Kisco, New York, 1960), vol 3, s 407 [Williston]. Similarly F C Woodward "Assignability of Contract" (1904) 18 Harv L Rev 23, 23 (the phrase "assignment of contract" is one of no precise significance), G C Grismore "Is the Assignee of a Contract Liable for the Non-Performance of Delegated Duties?" (1920) 18 Mich L Rev 284, 286 (notes that the courts have used "assignment of contract" to refer indiscriminately to situations that are fundamentally different, and argues that that phrase should be discarded entirely); Farnsworth above n 7, 125 (United States courts often fail to use "assign" with precision). English texts also call for clear terminology. See, for example, G H Treitel The Law of Contract (8 ed, Sweet \& Maxwell, London, 1991) 603-604 (although the phrase "assignment of liabilities" is occasionally used, it is highly misleading and should be abandoned).

13 This article refers to "common law" in the sense of non-statutory law.

14 Section 130(1) of the Property Law Act 1952, containing a method of assignment, also provides that rights so assigned are "subject to all equities that would have been entitled to priority over the right of the assignee if this Act had not been passed". "Subject to equities" means that, if the assignee seeks to enforce the assigned rights against the non-assigning party, the non-assigning party can (as a defence) set up any defence, set-off, counterclaim (of certain types) or other answer that it could have set up against a claim by the assignor at the time it received notice of the assignment: Roger Fenton Laws of New Zealand Choses in Action (Butterworths, Wellington, 1993) paras 49 and 50 .

15 Tito v Waddell (No 2) [1977] Ch 106, 290 [Tito]. 
Templeman accepted that conditions relevant to the exercise of a right could be attached to that right in express terms or by implication. ${ }^{16}$

This can occur when the assignor must perform certain obligations prior to and as a condition of the non-assigning party performing its obligations. After the assignor assigns its rights to the assignee, the assignee is in no better position than the assignor. Thus, the assignee must perform the assignor's obligations itself (or have someone else do so) ${ }^{17}$ before it can enforce its rights against the non-assigning party. This principle has been explained as follows: ${ }^{18}$

The fact that an assignment of rights does not in itself impose liability for performance upon the assignee, does not mean that the assignee may enforce the contract if the obligations which it imposes are not performed by either the assignee or the assignor. On the contrary, the assignee takes the rights with all the burdens to which the rights were subject in the hands of the assignor and if he undertakes to enforce the rights by an action, he must show that the conditions have been performed either by his assignor or by himself.

This principle was applied in Field $v$ Fitton, ${ }^{19}$ where a buyer assigned its interests under an agreement for sale and purchase of land. The Court of Appeal held that the assignees were not entitled to have the land transferred to them as neither they (nor anyone else) had performed the assignor's obligations under the agreement. By way of contrast, in HEB Contractors Limited $v$ Verrissimo ${ }^{20}$ an assignee who had fulfilled the assignor's obligations under an agreement for sale and purchase of land was granted specific performance of that contract.

Thus there is a risk for assignees relying on assigned rights where their ability to enforce those rights depends on the performance of obligations (especially performance by

16 Rhone v Stephens [1994] 2 AC 310, 322 (HL) [Rhone].

17 This assumes that the original contract expressly or impliedly allows persons other than the assignor to perform the assignor's obligations: see below $\mathrm{n} 55$.

18 Anderson on the Uniform Commercial Code (3 ed, The Lawyers Co-operative Publishing Co, Rochester (NY), 1982) vol 2, s 2-210:64.

19 Field v Fitton [1988] 1 NZLR 482 (CA) [Field]. Similarly Isaac Construction Company Ltd v McDonald (1998) 3 NZ Conv C 192,707 (CA).

20 HEB Contractors Limited v Verrissimo [1990] 3 NZLR 754 [HEB Contractors]. 
someone other than the assignee), such as banks who are assigned, as security for a loan to the assignor, the assignor's rights under an executory contract. ${ }^{21}$

In Tito, Megarry V-C held that there is also a "pure principle of benefit and burden" whereby independent burdens pass because "he who takes the benefit must bear the burden". ${ }^{22}$ However, the "pure principle" has been rejected. ${ }^{23}$

\section{Section 11 of the Contractual Remedies Act 1979}

\section{Section 11(1) refers to assigning contracts, benefits and burdens}

In other jurisdictions, references to assigning a contract, or both contractual rights and obligations, can be dismissed as semantic imprecision. In New Zealand such references may also reflect the uncertainty created by sections 11(1) and 11(2) of the Contractual Remedies Act 1979, which state:

(1) Subject to this section, if a contract, or the benefit or burden of a contract, is assigned, the remedies of damages and cancellation shall, except to the extent that it is otherwise provided in the assigned contract, be enforceable by or against the assignee.

(2) Except to the extent that it is otherwise agreed by the assignee or provided in the assigned contract, the assignee shall not be liable in damages, whether by way of set-off, counterclaim,

21 Furmston, above n 9, 44, gives the example of a contractor assigning at the outset his right to payments under a contract under which the contractor is to construct a building. Furmston states that "it seems very doubtful whether the contract can effectively separate the right to be paid from the duty to put up the building, so as to transfer the right to be paid to his bank and leave the duty to put up the building unaffected" and "although the burden of performing the contract is still on the contractor, it is also in some sense on the bank, to the extent that the work is done defectively or late". See Batavian Bank v Minneapolis St P \& S S M Ry Co (1904) 101 NW 687 where an assignee bank, to prevent its right to receive funds being subject to set-offs, obtained a direct acknowledgement from the non-assigning party that it was to pay the bank and that it could only deduct certain types of charges from such payments.

22 Tito above $\mathrm{n} 15,292$ and 302.

23 See Rhone above n 16, 322 and Government Insurance Office (NSW) v K A Reed Services Pty Limited [1988] VR 829, 841 (Full Court of the Supreme Court of Victoria) where Brooking J stated that the "pure principle" is "founded upon authority that will not sustain it and at odds with settled and fundamental rules". However, see C J Davis "The Principle of Benefit and Burden" [1998] CLJ 522, 523,540 and 547 who argues that there is an established principle of benefit and burden in English law, that in many respects this principle is simply an extension of conditional rights, and that perhaps Megarry V-C only found it necessary to call it a new principle because he took a restrictive approach to conditional rights. Some United States cases in effect adopt the pure principle: see, below nn 88 and 93. While some New Zealand judgments refer in general terms to assignees of rights also having to bear obligations, it is submitted that, read in context, these refer to conditional rights rather than endorsing the "pure principle." See, for example, Field above $\mathrm{n}$ 19, 492 and Gibbston Valley above n 4, 10 per Tipping J. 
or otherwise, in a sum exceeding the value of the performance of the assigned contract to which he is entitled by virtue of the assignment.

[Emphasis added.]

The courts have not definitively interpreted section 11 insofar as it relates to assigning obligations. ${ }^{24}$ There are at least three possible interpretations.

The first interpretation (favoured by the author) assumes that, while business people, lawyers and even courts sometimes loosely refer to assigning "a contract" (or both rights and obligations), ${ }^{25}$ it is unlikely that a legislative drafter would deliberately use inaccurate language. ${ }^{26}$ Thus, section 11(1) appears to have been drafted on the mistaken assumption that parties can assign contractual obligations (and hence contracts as a whole). Furthermore, the language used in section 11(1) (that is, "if" a contract, benefit or burden is assigned) means that section 11(1) does not enable obligations to be assigned, but only deals with the consequences if they are assigned. Thus, in accordance with the view expressed in various texts, ${ }^{27}$ the reference in section 11(1) to assigning the "burden of a contract" has no effect.

24 In Gibbston Valley above n 4, 8, Henry and Blanchard JJ stated that s 11(1) "does not yet appear to have been the subject of judicial attention". Decisions referring to assignment of a "contract" under s 11 do not turn on whether parties can assign contractual obligations. See for example Adams Fabrics v Monk (2 May 1989) unreported, High Court, Christchurch Registry, CP 189/87. In Waimate Land Development Limited v Morven Glenavy Ikawai Irrigation Co Limited (7 March 1996) unreported, High Court, Timaru Registry, CP 7/93 (appeal allowed on other grounds: (28 October 1997) unreported, Court of Appeal, CA250/96), where the assignability of obligations was in issue, the point was argued but left open. The reports leading to the enactment of the Contractual Remedies Act 1979 do not explain what is meant by the "burden of a contract": "Misrepresentation and Breach of Contract", Report of the Contracts and Commercial Law Reform Committee presented to the Minister of Justice in March 1967, [CCL Report] and Further Report on Misrepresentation and Breach of Contract, January 1978.

25 Thus it may be appropriate to give meaning to such language when used in transactions: see below Parts IV B and V, and below $\mathrm{n} 113$.

26 Another possible explanation is that s 11(1) was intended to refer to "a contract, or the benefit and burden of a contract." This would explain the reference to "the assigned contract" and would also have avoided the odd result that a person assigned only obligations can be subject to damages under s 11(1) but, unless otherwise agreed, such damages are set at zero because of the limitation on liability in s 11(2) (and hence the assignee is not subject to any remedy under s 11(1) given that cancellation is not an effective remedy against an assignee with only obligations).

27 J Burrows, J Finn and S Todd Law of Contract in New Zealand (Butterworths, Wellington, 1997) 582 A Borrowdale (ed) Commercial Law in New Zealand (3 ed, Butterworths, Wellington, 1996) 122; and F Dawson and D McLauchlan The Contractual Remedies Act 1979 (Sweet \& Maxwell, New Zealand, 1981) 192. 
A second interpretation was suggested in the recent Court of Appeal case of Gibbston Valley Estate Limited $v$ Owen. ${ }^{28}$ Given their other findings, Henry and Blanchard JJ considered that it was "unnecessary to express a concluded view upon the meaning and effect of subs(1) of s11 of the Contractual Remedies Act". ${ }^{29}$ However, in obiter statements in his separate judgment, Tipping J discussed section 11 - and did not limit it to the assignment of contractual rights: ${ }^{30}$

The section deals with three potential situations: (1) the assignment of a contract as a whole;

(2) the assignment of the benefit of a contract; and (3) the assignment of the burden of a contract.

. . . The conceptual severance of benefit and burden, both from each other and from the contract as a whole, which the section adopts, is apt to cause difficulties.

When a contract as a whole is assigned, the assignment is necessarily of all such benefits and burdens as arise thereunder. The effect of an assignment of this kind is the same as if the applicable benefits and burdens had both been individually assigned.

What, then, did Tipping J mean by the "assignment" of obligations? His Honour added that the assignment of obligations does not relieve the assignor of those obligations as regards the non-assigning party; that is, the non-assigning party could still enforce those obligations against the assignor. ${ }^{31}$ Thus, Tipping J interpreted references to assigning "a contract" or the "burden of a contract" in light of accepted methods of "transferring" obligations; that is, as meaning (or, in the case of assignment of "a contract", including) a delegation of obligations with the assignor remaining liable for any default in performance. $^{32}$

28 Gibbston Valley above $\mathrm{n}$ 4. This approach is similar to that of Dawson and McLauchlan, above $\mathrm{n}$ $27,195$.

Gibbston Valley above n 4, 8.

30 Gibbston Valley above n 4, 10. Similarly, in delivering the judgment for the Court of Appeal in Mountain Road (No 9) Limited v Michael Edgley Corporation Pty Limited [1999] 1 NZLR 335, 337 (CA) [Mountain Road], Tipping J stated that provisions in issue there "make it clear that not only are the assignor's rights being assigned, but also its duties and obligations." His Honour's approach could be based either on the assumption that the legislative drafter deliberately used inaccurate (but common) terminology or on the assumption that the drafter was mistaken as to the assignability of obligations but the courts should nevertheless seek to give effect to all parts of $\mathrm{s}$ 11. In contrast, Fraser J in the High Court judgment in Gibbston Valley referred to the buyer's burden under the agreement for sale and purchase being "not assignable": Gibbston Valley Estates Limited $v$ Owen (1998) 3 NZ Conv C 192,840, 192,848.

31 Gibbston Valley above n 4, 10-11.

32 See below Parts III A and B. 
Under this interpretation, it is unclear whether the references in section 11(1) to assigning a contract or the burden of a contract should apply only to contracts or obligations that are purported to be "assigned" or whether they also extend to obligations that are "transferred", "delegated" or otherwise intended to be performed by the assignee.

The third interpretation treats section 11(1) as enabling the assignment of obligations (and hence contracts as a whole). This could mean, by analogy with the assignment of rights, that those obligations pass to the assignee, with the non-assigning party able to seek a remedy against the assignee but not the assignor. To some extent, this would be consistent with consumer legislation under which assignees are subject to the same remedies as were their assignors. However, unlike section 11, such legislation explicitly preserves the non-assigning party's remedies against the assignor. ${ }^{33}$

Enabling a party to transfer obligations without the non-assigning party's consent would represent a significant break from the common law - which courts are reluctant to find $^{34}$ - and raise the difficulties that led to the common law prohibition on assigning obligations. ${ }^{35}$ Section 11 would go even further, by potentially denying the non-assigning party a remedy against both assignor and assignee. ${ }^{36}$ Thus, this interpretation should not be adopted.

\section{Applying section 11(1)}

As well as uncertainty as to whether obligations can be "assigned" - and, if so, what this means and the transactions falling within section 11(1) - section 11(1) is uncertain in another respect. ${ }^{37}$

The reference in section 11(1) to remedies being enforceable "by or against the assignee" could apply in its entirety to assignees who are assigned rights or (if effective) a contract or obligations. Thus, the non-assigning party could enforce remedies against an assignee of rights ${ }^{38}$ for any default in performance of obligations "assigned" to the assignee, or perhaps

33 See below Part II D and below $\mathrm{n} 48$.

34 See Rasch below $\mathrm{n} 50$ and Linden below $\mathrm{n} 51$.

35 See below Part II A.

36 As noted in above $\mathrm{n}$ 26, following an assignment of obligations without a corresponding assignment of rights, the remedy of cancellation in s 11(1) would not be an effective remedy against the assignee, and nor would the assignee be liable for damages (unless otherwise agreed). Thus, an assignor would not even need an "obliging insolvent" (above n 7) but could merely assign its obligations to any other person while keeping its rights for itself.

37 The two interpretations in this section are found in Burrows et al, above n 27, 582-583.

38 The limitation in s 11(2) (assignee not liable in damages in a sum exceeding the value of the performance of the assigned contract to which the assignee is entitled) means that, unless otherwise agreed, the assignee must have been assigned rights before the assignee can be liable. 
any obligations under the contract (subject to the limitation on liability in section 11(2)). Section 11 would then enable a non-assigning party to bring an action against the assignee (rather than merely being able to set up equities as a defence against a claim by the assignee). This interpretation was recently endorsed by way of obiter dicta by Randerson J in Impact Collections Limited $v$ Cornerstone Group Limited ${ }^{39}$ and by Tipping J in Gibbston Valley. ${ }^{40}$

However, there is another interpretation open. The phrase "by or against the assignee" could refer respectively to remedies being enforceable by assignees who have been assigned benefits (by themselves or as part of a contract) and being enforceable against assignees who have been assigned burdens (by themselves or as part of a contract). If references to assigning contracts or burdens have no effect, section 11(1) would not then expose assignees to greater risks than at common law. ${ }^{41}$ If, however, section 11 (1) covers the delegation of obligations or enables the assignment of obligations, then the nonassigning party could seek remedies against the assignee (subject to the limitation on liability in section 11(2)).

\section{Conclusion on section 11}

It is unclear to what extent section 11 of the Contractual Remedies Act 1979 modifies the general principle that, subject to various qualifications, obligations cannot be assigned. There are few cases on section 11 - and none definitively interpreting it. Section 11 might have no effect on the assignment of obligations; at the other extreme it might make obligations generally assignable; or could mean that a non-assigning party can seek damages from an assignee (up to the value of the performance of the assigned contract to which the assignee is entitled by virtue of the assignment) if the assignee's (or perhaps others') obligations under the contract are not performed.

This uncertainty creates difficulties for commercial lawyers in transferring contractual obligations (and contracts as a whole) and in determining the consequences of past

39 Impact Collections Limited v Cornerstone Group Limited (6 May 1999) unreported, High Court, Auckland Registry, AP 6/09.

40 Gibbston Valley above n 4, 10. Furthermore, Henry and Blanchard JJ, after stating that it was unnecessary to express a concluded view on s 11(1), added at 8 that s 11(1) "appears to provide that where the benefit of a contract is assigned, the other party to the contract ... has a remedy in damages against the assignee if there is a breach of the assignor's obligations under the contract, subject to the limitation on quantum of damages". This interpretation would be consistent with the CCL Report, above n 24, para 19.8.

41 Under this interpretation, s 11(2) can be treated as having no effect (being based on the mistaken assumption that obligations are assignable) or as codifying the common law principle that assignees' rights are subject to equities (above $\mathrm{n} 14$ ). 
transfers. Thus, section 11 should be amended (or authoritatively interpreted by the courts) to clarify its intended effect.

\section{Statutory Transfers of Certain Contractual Obligations}

Specific legislation can directly or in effect override the principle that contractual obligations are not assignable. For example, the State-Owned Enterprises Act 1986 enables shareholding Ministers to transfer to a state-owned enterprise Crown assets and liabilities (including liabilities under any contract) 42 "notwithstanding any restriction, prohibition, or other provision contained in any ... rule of law ... that would otherwise apply". 43 Third persons must then deal with the state-owned enterprise in place of the Crown. ${ }^{44}$ However, such transfers mirror the common law position ${ }^{45}$ to some extent by providing that: ${ }^{46}$

The Crown shall remain liable to any third party as if the asset or liability had not been transferred but shall be indemnified by the State enterprise in respect of any liability to that third party.

Similarly, while consumer legislation often enables non-assigning parties to exercise remedies against assignees subject to various limits, ${ }^{47}$ such legislation typically also

42 Section 29(1) of the State-Owned Enterprises Act 1986.

43 Sections 23 and 29(3) of the State-Owned Enterprises Act 1986. In contrast, when companies amalgamate there is no assignment or transfer of rights and obligations from the amalgamating companies to the amalgamated company but rather the amalgamated company, as the continuing entity, succeeds to those rights and obligations and "stands in the shoes" of the amalgamating companies: Carter Holt Harvey Limited v McKernan [1998] 3 NZLR 403 (CA).

44 Section 23(5) of the State-Owned Enterprises Act 1986.

45 At common law, an assignor who has also delegated or subcontracted the performance of its obligations remains liable to the non-assigning party if those obligations are not performed: see below Parts III A and III B.

46 Section 23(5)(d) of the State-Owned Enterprises Act 1986. Similarly, in the 1993 health reforms the Minister of Finance, Minister of Health and the Governor-General, were given powers to transfer both assets and liabilities of the Crown and various government entities to (as they were then) regional health authorities and crown health enterprises without breaching any rule of law prohibiting the transfer: ss 4, 5 and 6(1) of the Health Reforms (Transitional Provisions) Act 1993. After the transfer, the Crown was liable to any third parties as if the assets or liabilities were those of the Crown but was to be indemnified by the transferee in respect of any such liability: ss $6(2)(\mathrm{c})$ and (d) of the Health Reforms (Transitional Provisions) Act 1993.

47 See ss 2 (definition of "supplier") and 46(1) of the Consumer Guarantees Act 1993 and ss 2(1) (definitions of "purchaser" and "vendor"), 18(1) and 21(3) of the Hire Purchase Act 1971. 
provides that assignors do not, by virtue of the assignment, shed their obligations under the contract. ${ }^{48}$

The provisions enabling local authorities to establish local authority trading enterprises (LATEs) mirror the common law position even more closely - only allowing transfers of obligations where the local authority, LATE, the person to whom the obligation is owed and any guarantor agree to the transfer. ${ }^{49}$

Thus, even when specific legislation authorises transfers of contractual obligations, Parliament is reluctant to allow parties to escape their obligations by transferring them. Furthermore, the courts are reluctant to interpret legislation so as to find a right to transfer obligations where this is not express, ${ }^{50}$ or to hold that a transfer of obligations relieves the transferor of ongoing liability for performance of those obligations. ${ }^{51}$

\section{MEANS OF TRANSFERRING OBLIGATIONS}

\section{A Delegation $^{52}$}

While contractual obligations are generally not assignable, there are several means of "transferring" 53 obligations in some senses - with various degrees of effectiveness

48 See for example s 46(4) of the Consumer Guarantees Act 1993 and ss 18(5) and 21(4) of the Hire Purchase Act 1971.

49 Sections 594ZI and 594ZK of the Local Government Act 1974.

50 Wellington City Council v Rasch [1995] 2 ERNZ 91, 96 (CA) (while Parliament can legislate away an employee's right not to have his or her employment contract transferred without consent, the Court will expect such an intention "to be plainly stated") [Rasch].

51 See Effort Shipping Co Limited v Linden Management SA [1998] AC 605 (HL) [Linden].

52 Part III A of this article discusses delegation (and corresponding vicarious performance by the assignee) where there is no contract between the delegator and delegate binding the delegate to perform the obligations. Delegation under such a contract is discussed in Part III B.

53 Just as it is incorrect to refer to "assigning" obligations, strictly speaking none of the other methods discussed in Part III "transfer" obligations. See for example Treitel, above n 12, 604. Thus, references in this article to "transfers" of obligations refer to transfers in a practical sense rather than transfers in a strict legal sense. 
depending on the objectives of the transfer. ${ }^{54}$ For example, subject to certain exceptions, ${ }^{55}$ a party to a contract need not perform its obligations itself if another person ("delegate") performs those obligations on its behalf. ${ }^{56}$ However, the delegator remains liable to the other contracting party for any default in performance. ${ }^{57}$

In some circumstances the delegator keeps the benefit of the contract for itself. ${ }^{58}$ In other cases the delegator also assigns its contractual rights to the delegate. These alternatives can be shown diagrammatically as follows:

54 Novation is the most effective if the transferor's primary objective is to avoid liability for future performance of obligations. However, other methods are more effective where the transferor seeks to transfer obligations without the consent of the other party to the original contract.

55 Most significantly, obligations cannot be delegated if the contract prohibits delegation or if they are personal in nature: Tolhurst $v$ Associated Portland Cement Manufacturers (1900) Limited [1902] 2 KB 660 (CA), 669 (affd [1903] AC 414 (HL)). In M v B (1998) 6 NZBLC 102,463, 102,469 Williams J stated that "a party to a contract is at common law entitled to perform that contract through an agent unless the contract is one which expressly or impliedly excludes vicarious performance or is so personal as to be regarded as incapable of that mode of performance". A prohibition on a party assigning rights may also point towards that party being unable to delegate its obligations: Jeffrey $v$ DB Breweries Ltd (19 February 1999) unreported, High Court, Auckland Registry, HC 158/98, 1719.

56 HEB Contractors above n 20, 763.

57 British Waggon Co v Lea (1880) 5 QBD 149, 154 [British Waggon].

58 This would be more common when the delegator and delegate enter into a subcontract under which the delegator provides other consideration for the delegate's performance. See below Part III B. 
If it does not have a contract with the delegate, the delegator cannot (as a matter of contract law) compel the delegate to perform the delegator's obligations. Neither can the other party to the original contract sue the delegate in contract for default. ${ }^{59}$

While as a matter of contract law the delegate need not perform the obligations, in commercial terms this may not be so. Where the delegation is accompanied by an assignment of the delegator's rights, a delegate wishing to enforce those rights against the non-assigning party must perform any obligations on which those rights depend (or have someone else do so). ${ }^{60}$ As stated in Cooper v Micklefield Coal and Lime Company Limited: ${ }^{61}$

It is, of course, true that the assignee cannot insist on the continued performance of the contract unless either his assignor is able and willing to satisfy the obligation to pay, or the assignee himself is willing to do it for him. In that sense at least, apart from novation, the obligation to pay is doubly secured after the assignment, because there is not only the continuing personal liability of the assignor, but the necessity upon the assignee, of performing the obligations ....

\section{B Subcontracting}

Subcontracting is similar to delegation as discussed above in Part III A except that the delegator and delegate enter into a contract binding the delegate to perform the delegator's obligations under the original contract. As was the case in Part III A, the delegator might also assign its rights under the original contract. Shown diagrammatically:

59 Where the delegate has been assigned rights, this conclusion may be affected by s 11 of the Contractual Remedies Act 1979. See above Part II C.

60 See above Part II B.

61 Cooper v Micklefield Coal and Lime Company Limited (1912) 107 LT 457, 458. The author agrees with views expressed elsewhere that the necessity referred to in this passage is the practical necessity of the delegate performing the assignor's obligations if it wants to enforce the assignor's rights; the delegate is not legally obliged to perform the delegator's obligations: P Megens and B Ang "Assignment, Novation and Subcontracting - Who Cares What You Call It?" (1994) 10 Building and Construction Law 319, 323. 
The Court of Appeal has recently categorised assignments included as part of a contract between the assignor and assignee as "contractual" assignments. In Mountain Road $^{62}$ an assignor, by a memorandum of agreement of assignment, transferred all its rights in and benefits to be derived from a tent in return for the assignee agreeing to assume the assignor's duties and obligations in relation to the tent. Tipping J described the nature of the transaction as follows: 63

Whatever the position may be in other cases, this case involved a contractual assignment, not a voluntary assignment .... .

This assignment ... was undoubtedly intended to be contractual in nature. [The assignee] was providing consideration by its agreement to take over [the assignor's] obligations.

A subcontract between an assignor and assignee does not affect the assignor's responsibility for performance vis-à-vis the non-assigning party. Thus, if the assignee fails to perform the assignor's obligations, the assignor is in breach of its contract with the nonassigning party. ${ }^{64}$

Nor does the subcontract in itself create a contract between the assignee and the nonassigning party ${ }^{65}$ or otherwise enable the non-assigning party to sue the assignee - unless the non-assigning party can rely on section 11 of the Contractual Remedies Act 1979 or on section 4 of the Contracts (Privity) Act 1982. Under the Contracts (Privity) Act 1982, the non-assigning party can bring proceedings against the assignee if the subcontract confers, or purports to confer, rights on the non-assigning party ${ }^{66}$ (except where the subcontract on its proper construction is not intended to give the non-assigning party the right to sue the

62 Mountain Road above n 30.

63 Mountain Road above n 30, 339-340.

64 British Waggon above n 57, 154; Southway Group above n 8, 43 and 53.

65 Southway Group above n 8, 53. However, see Olympic Corporation Limited v Orcatory Road Properties Limited [1990] 2 NZLR 519 (CA) in which a seller, who was liable to pay rent to a third party, sold its business on the basis that the seller would transfer its leasehold estate to the buyer and the buyer would indemnify the seller for any rent the buyer failed to pay to the third party. The buyer refused to take an assignment of the leasehold estate and did not pay the rent. The issue was whether the seller, who had paid the third party, could seek an indemnity from the buyer. Richardson and Bisson JJ stated at 527, apparently obiter, that the assignment imposed on the buyer a contractual liability to the third party. For criticism of the majority's reasoning, see C Corry "Contractual Obligations of an Assignee" (1990) 5 BCB 165. As was the case for delegation without a subcontract, above n 59, s 11 of the Contractual Remedies Act 1979 may enable the nonassigning party to seek remedies from a subcontractor who has been assigned rights.

66 The non-assigning party must also be sufficiently designated in the subcontract. This is unlikely to cause difficulties in this context. 
subcontractor). Otherwise, the non-assigning party can only sue the assignor (who could in turn, subject to the terms of the subcontract, sue the assignee).

\section{Novation}

Novation is another means by which contractual obligations can be "transferred" from one person to another. In Southway Group Limited v Wolff, 67 Bingham LJ stated:

If $\mathrm{A}$ wishes to assign the burden of the contract to $\mathrm{C}$ he must obtain the consent of $\mathrm{B}$, upon which the contract is novated by the substitution of $\mathrm{C}$ for $\mathrm{A}$ as a contracting party.

In this context, 68 a "novation" occurs when a contract between A and B is replaced with a contract between $B$ and $C$ under which $C$ has the same rights and obligations as did $A$ under the original contract. In effect, $\mathrm{C}$ replaces $\mathrm{A}$ in the contractual arrangements with $\mathrm{B}$. This can be shown diagrammatically as:

$\mathrm{B}$ must agree to this rearrangement - both to the termination of the original contract between $\mathrm{A}$ and $\mathrm{B}$ and to the formation of the new contract between $\mathrm{B}$ and $\mathrm{C} .{ }^{69}$

67 Southway Group above n 8, 52. For a detailed analysis of the nature and elements of novation, see J Bailey "Novation" (1999) 14 Journal of Contract Law 189. Bailey states, at 220, that "[i]f it were possible for contractual obligations to be assigned ... novation would be all but banished into the oblivion of legal history".

68 "Novation" can be used more generally to describe a new contract substituted for an existing contract, either between the same parties or between different parties: Scarf $v$ Jardine (1882) 7 App Cas 345, 351 per Lord Selborne LC.

69 The other elements of contract formation must also be present for the new contract between B and C (for example consideration, any formalities). Where a contract contemplates that a party can substitute another person for itself, it has been suggested that the substitution is not a novation as the substituting party performs rather than terminates the original contract: Australian National Airlines Commission v Commissioner of Stamp Duties (Qld) (1987) 87 ATC 4,218 [Australian National Airlines]. 
From A's perspective, the main advantage of a novation is that it creates a "clean break"; that is, subject to the terms of the rearrangement agreed between the parties, ${ }^{70} \mathrm{~A}$ does not have ongoing obligations to $\mathrm{B}$ once it terminates its contract with B. ${ }^{71}$ Rather, B can sue $C$ directly under its contract with $C$ if $C$ does not perform. Novation is the only means enabling A to "transfer" its obligations in the sense that A is no longer liable for any default in the performance of obligations. ${ }^{72} \mathrm{C}$ may also prefer a novation as, subject to the terms of the rearrangement agreed between the parties, C's rights are not then subject to equities resulting from anything done by $\mathrm{A}$.

While novations can be effected formally (for example by the parties entering into a deed of novation or exchanging other documentation), novations can also be effected informally. In Karangahape Road International Village Limited $v$ Holloway ${ }^{73}$ Chilwell J stated: ${ }^{74}$

Novation can be inferred from acts and conduct but ordinarily it is not to be inferred from conduct without some distinct request.

In that case, Mr and Mrs Holloway agreed to sell land to Jackson "or nominee". Jackson nominated Karangahape Road International Village Limited as nominee. That company argued that there had been a novation creating a contract between itself and the Holloways (and terminating the contract between Jackson and the Holloways) based on conduct such as the Holloways executing a memorandum of transfer to the company and addressing their settlement statement to the company. The Court held that there was insufficient evidence of a novation by conduct, as the conduct was consistent with an alternative explanation (that is, that the company remained Jackson's nominee for the purposes of completing the contract).

70 Formal deeds of novation and novation agreements often provide that A remains liable to B for any breach of its obligations before the date of the novation but is not liable for any breaches after that date.

71 However, parties to commercial contracts must often rely instead on an assignment accompanied by a delegation or subcontracting of obligations, as B may not consent to a novation (or seeking consent may give $\mathrm{B}$ an opportunity to renegotiate the substance of the contract).

72 Southway Group above n 8, 43.

73 Karangahape Road International Village Limited v Holloway [1989] 1 NZLR 83, 101.

74 In Cooper $v$ Commissioner of Inland Revenue (1995) 17 NZTC 12,216, 12,223 Cartwright J stated that the novation in that case did not have to be in writing and "consent may be inferred from acts and conduct in the absence of rebutting circumstances". See also Rouse v Bradford Banking Company [1894] 2 Ch 32, 54 and 72 (CA) and Chatsworth Investments Limited v Cussins (Contractors) Limited [1969] 1 All ER 143, 144 (CA) per Lord Denning MR. 
Ultimately, whether or not there is a novation - as against another type of transaction depends on the parties' intention. ${ }^{75}$

\section{PURPORTED ASSIGNMENTS OF OBLIGATIONS}

\section{A New Zealand, English and United States Frameworks Differ}

As explained above, contractual obligations generally cannot be assigned, but they may be able to be "transferred" by delegation (either with or without a subcontract) or by novation.

However, inaccurate terminology used in relation to such transfers creates difficulties. Contract law is based on discerning the parties' (to some extent fictitious ${ }^{76}$ ) intention. When the parties use language at odds with the underlying legal principles, their intention can be obscured.

What, then, is the effect of a purported "assignment" of obligations (either by themselves or as part of a purported assignment of a contract)? ${ }^{77}$ In English law, the approach proposed in the House of Lords ${ }^{78}$ is to construe references to assigning "a contract" as assigning only the rights under that contract. Beyond this, English common law offers few guiding principles. In New Zealand the position is no clearer in the absence of an authoritative interpretation of section 11 of the Contractual Remedies Act 1979.

In contrast, the United States common law has developed a framework for such transactions, based in part on presumptions of interpretation. This framework is designed to give as full effect as possible (in the absence of the non-assigning party's consent) to the intention that the assignee be substituted for the assignor. ${ }^{79}$ Parts IV B to IV E of this

75 Vickery $v$ Woods (1952) 85 CLR 336, 345 (HCA).

76 It is a basic premise of contract law that interpreting contracts involves ascertaining the parties' objective intention, rather than their subjective intention(s). As stated by Lord Hoffman in Investors Compensation Scheme Limited v West Bromwich Building Society [1998] 1 All ER 98, 114 (HL), interpretation "is the ascertainment of the meaning which the document would convey to a reasonable person having all the background knowledge which would reasonably have been available to the parties in the situation in which they were at the time of the contract".

77 While Part IV of this article is relevant both to a purported assignment itself and to an assignment provision in the original contract, Part V examines "prospective substitution provisions" in their own right.

78 See above Part II A.

79 Restatement of the Law Second, Contracts 2d, s 328(1), comment. H O Hunter "Commentary on 'Assignment of Contractual Burdens'"(1998) 13 Journal of Contract Law 51, 54 describes the United States position as that "for all intents and purposes, [the assignee] is akin to a substituted party in a novation". 
article examine the United States framework, and compare it with the position in New Zealand and England.

\section{B Assignor's Intention to Delegate Obligations as Well as Assign Rights}

Most United States jurisdictions use the following presumptive rule of interpretation: ${ }^{80}$

Unless the language or the circumstances indicate the contrary, as in an assignment for security, an assignment of "the contract" or of "all my rights under the contract" or an assignment in similar general terms is an assignment of the assignor's rights and a delegation of his unperformed duties under the contract.

This reflects what the parties in the majority of such transactions are thought to have intended: 81

The presumption seems reasonable in view of the evident expectation of the parties ... [The assignment] purports to transfer the contract as a whole, and since the contract is made up of both benefits and burdens both must be intended to be included ... [C]ommon sense tells us that the assignor, after making such an assignment, usually regards himself as no longer a party to the contract.... The assignee on the other hand understands that he is to carry out the terms of the contract as is shown by the fact that he usually does, most of the decided cases being those in which the other party objected to performance by the assignee.

This presumption can be overridden when the language of the assignment or surrounding circumstances suggests that the assignment is not of a contract as a whole but is limited, for example, to what is due or to become due under a contract. ${ }^{82}$

In contrast, New Zealand and English courts must examine the assignment of "a contract" in light of the contract as a whole and surrounding circumstances before concluding that an assignor intends to delegate obligations as well as assign rights. ${ }^{83}$ Moreover, applying Lord Browne-Wilkinson's analysis could lead to the conclusion that

80 Restatement of the Law Second, Contracts 2d, s 328(1). Similarly, ss 2-210(4) of the Uniform Commercial Code.

81 Grismore, above n 12, 288, quoted with approval in Rose v Vulcan Materials Company (1973)194 SE 2d 521, 534. Similarly Bilateral Contract above n 6, 941 (in the usual case the assignor's obvious purpose is to substitute another's performance as far as possible).

82 Chapin $v$ Pike (1903) 68 NE 42, 43. See also Chatham Pharmaceuticals, Inc v Angier Chemical Co, Inc (1964) 196 NE 2d 852 (assignment of the assignor's "right, title and interest" in a contract where that contract itself distinguished between the assignment of rights and obligations was only an assignment of rights).

83 However, if the approach of Tipping J to s 11 of the Contractual Remedies Act 1979 was adopted (see above Part II C 1), then the courts would presumably be more likely to hold that a purported assignment of a contract involved a delegation of obligations as well as an assignment of rights. 
references to assignment of "a contract" mean only an assignment of rights, without an accompanying delegation.

It is submitted that, in most cases where "a contract" is assigned, it is reasonable to assume that the assignor intends the assignee to perform its obligations. Therefore, the explicit presumption used in the United States would be useful here, as it would make a court's ruling as to the assignor's intention more predictable (with such a ruling being likely to mirror that intention in practice).

\section{Assignee's Liability to the Assignor}

Most United States jurisdictions also use a further presumption: ${ }^{84}$

Unless the language or circumstances indicate the contrary, the acceptzance by an assignee of [an assignment of "a contract", etc] operates as a promise to the assignor to perform the assignor's unperformed duties....

As before, the justification for this presumption is that it reflects what most parties actually intend. ${ }^{85}$ Consequently, it is also justified as assisting commercial transactions: ${ }^{86}$

The rule of presumptive interpretation ... makes sense for commercial transactions involving assignments, particularly where it is the regular business of the assignee to render the incomplete performance.

Ultimately the presumption is only that: whether or not the assignee is bound to the assignor to perform the assignor's obligations depends on the parties' intentions as shown by their acts, words and subject matter of the contract. ${ }^{87}$

84 Restatement of the Law Second, Contracts 2d, s 328(2). Similarly, ss 2-210(4) of the Uniform Commercial Code. This has not been consistently adopted by United States courts: Williston above $\mathrm{n} 12$, s $418 \mathrm{~A}$.

Grismore, above n 12, 288, as quoted in above Part IV B.

86 Keyes $v$ Scharer (1968) 165 NW 2d 498, 502.

87 Enterprise Leasing Corporation v Shugart Corporation (1991) 282 Cal Rptr 620, 624 [Enterprise Leaving]. 
Most United States jurisdictions hold that the implied assumption of obligations attached to an assignment creates an implied contract between the assignor and assignee. ${ }^{88}$ In New Zealand and England, where there is no such presumption, the courts may well reach the same result in many cases. However, this result is not guaranteed given courts' general reluctance to find an acceptance where conduct is ambiguous or, where there is otherwise a contract, to imply terms into that contract. ${ }^{89}$ This would be especially so where an alternative interpretation is that the assignment of "a contract" is an assignment of rights coupled with authority (that is, rather than an obligation) to perform the assignor's obligations.

If the United States presumption reflects what most parties actually intend, it would be efficient to adopt an equivalent presumption in New Zealand (whether in legislation or common law).

\section{$D$ Assignee's Liability to the Non-Assigning Party}

As in New Zealand and England, United States cases start with the principle that an assignment does not in itself make the assignee liable to the non-assigning party. ${ }^{90}$

In all these jurisdictions, if the assignee expressly or impliedly enters into a contract with, or otherwise directly assumes a binding obligation to, the non-assigning party to perform the assignor's obligations, the assignee is directly responsible to that party to do

88 See for example Cutting Packing Co v Packers' Exchange (1890) 25 P 52, Kirby Lumber Co v R L Lumber Co 279 SW 546 (1926), 549; and Williams v McWhorter (1923) 218 P 791, 793. Some judgments instead rely on equitable principles. These can include broad statements such as that the assignee "cannot require the assignor to continue to bear the burdens of the contract while he enjoys the benefits" - similar to the ill-fated "pure principle of benefit and burden" in English law referred to in above Part II B. (See for example Pioneer Loan \& Land Co $v$ Cowden (1915) 150 NW 903,905 .) See also Bilateral Contract above n 6, 942-943 (principle that the assignee must take the burdens with the benefits does not explain anything; assignee's liability must be on a promise implied from the acceptance of the assignment).

89 See generally Hon Justice Gallen, J Finn, C French Laws of New Zealand, Contract (Butterworths, Wellington, 1997) paras 33, 34, 109 and 112. On the other hand, in Circuit-Systems Ltd (in liq) $v$ Zuken-Redac (UK) Ltd [1996] 3 All ER 748, 758 (CA) Staughton LJ said "I wonder whether a purported assignment of burden may not have some effect as between the parties to it; in effect it may oblige the assignee to bear the cost of performance as against the assignor".

90 Langel v Betz (1928) 164 NE 890, 891 [Langel]; McGill v Baker (1928) 266 P 138, 141; Enterprise Leasing above $n 87,623$. 
so. ${ }^{91}$ Thus, New Zealand lawyers use various means to make an assignee directly responsible to the non-assigning party. ${ }^{92}$

Also, where there is a contract between assignor and assignee (either an explicit contract, or an implied contract applying the presumption set out above in Part IV C) United States courts generally allow the non-assigning party to sue the assignee for nonperformance, usually ${ }^{93}$ under the "third party beneficiaries" doctrine. ${ }^{94}$ This has been rationalised on the basis that: ${ }^{95}$

It is, perhaps, more in harmony with modern ideas of contractual relations than is "the archaic view of a contract as creating a strictly personal obligation between the creditor and debtor"

(Pollock on Contracts [9 Ed] 232) ....

As discussed above in Part III B, in New Zealand the non-assigning party may be able to sue the assignee by relying on section 4 of the Contracts (Privity) Act 1982 (equivalent to

91 Langel above n 90, 891.

92 For example, a party's ability to assign its rights under a significant commercial contract may be conditional on the assignee entering into a deed, in favour of the non-assigning party, in which the assignee undertakes to perform the assignor's obligations.

93 There are various other rationalisations (which can apply whether or not there is a contract between the assignor and assignee). Some cases hold that where the assignee performs the assignor's obligations, and thus interacts with the non-assigning party as if the assignee was a party to the contract, the assignee may be taken to have assumed the assignor's obligations vis-àvis the non-assigning party (for example Economic Water Heating Corporation v Dillon Supply Co (1931) 159 SE 78). Some cases even find assumption of obligations from an assignee accepting payments from the non-assigning party in accordance with the assignment of rights (for example Dahlhjelm Garages Inc v Mercantile Ins Co of America (1928) 270 P 434, 436), in contrast to the English position (Pan Ocean Shipping Limited v Creditcorp Limited [1994] 1 All ER 470 (HL) (assignee of receivables due under a charterparty who received an advance payment of hire not liable to repay it to the charterer in the event of hire not being earned due to the vessel being off hire for the relevant period)). Other United States courts have held that, where an assignee seeks specific performance from the non-assigning party, the assignee impliedly binds itself to perform the assignor's obligations (for example Couch v Crane (1914) 82 SE 459, 462). In other cases, the assignee's obligation to the non-assigning party has been expressed as arising from the doctrine of mutuality of liability (for example Blue Star Nav Co v Emmons Coal Mining Corporation (1923) 120 A 459,460 ). See Bilateral Contract above n 6, 943-944 (assignee cannot be liable on a promise implied from acceptance of the non-assigning party's performance because that performance cannot be consideration, given that the assignee was already entitled to it).

94 Rose $v$ Vulcan above $\mathrm{n} 81,533$ and 534. See Williston above $\mathrm{n}$ 12, ss 347, 356, 356A, 361 and 393 . In general terms, when a party to a contract promises to the other party to render performance to a third person, in most United States jurisdictions that third person can sue the promisor. In the assignment context, the third person will be a "creditor beneficiary" that is, the promisor's (assignee's) performance of the promise will satisfy obligations of the promisee (assignor) to the third party.

95 Langel above n 90, 892. 
the United States "third party beneficiaries" doctrine). However, non-assigning parties in New Zealand are worse off than their United States counterparts because (as discussed above in Part IV C) in New Zealand there is no presumption of a contract between the assignor and assignee when the assignor purports to assign a contract as a whole - a necessary element ${ }^{96}$ for a non-assigning party seeking to rely on the Contracts (Privity) Act 1982. Hence a non-assigning party suing a "defaulting" assignee in New Zealand has the onus of establishing such a contract at the outset.

On the other hand, in New Zealand the non-assigning party may be able to seek damages from an assignee by invoking section 11 of the Contractual Remedies Act 1979 although, for the reasons set out above in Part II C, the effect of section 11 is uncertain.

In practice, following the purported assignment of rights and obligations under a commercial contract, the assignor often plays no part in the ongoing operation of the contract (for example when contractual rights and obligations are "assigned" with the sale of a business). Thus, applying the United States presumptions, facilitating actions by the non-assigning party against the assignee would accord with business realities.

\section{E Assignor's Liability to the Non-Assigning Party}

In New Zealand and England an assignor is not released from its obligations to the non-assigning party merely by purporting to assign a contract as a whole; ${ }^{97}$ as such a release requires the non-assigning party's consent (whether by means of a novation or otherwise). ${ }^{98}$ United States courts take a similar approach: ${ }^{99}$

96 This assumes that the assignee has not entered into a deed conferring (or purporting to confer) a benefit on the non-assigning party.

97 See for example CB Peacocke Land Co Limited v Hamilton Milk Producers Co Limited [1963] NZLR 576, 583 [Peacocke] and the analysis of Tipping J in Gibbston Valley above n 8 (discussed above in Part II C 1).

98 See above Part III C.

99 Epland v Meade Insurance Agency Associates, Inc (1996) 545 NW 2d 401, 407 [Epland]. See also Restatement of the Law Second, Contracts 2d, s 318(3), Potts v Burkett (1926) 278 SW 471, 473, and Southern Concrete Company $v$ Carter Construction Company, Inc (1970) 174 SE 2d 447, 449. For example, in Clark v General Cleaning Company, Inc (1962) 185 NE 2d 749 [General Cleaning] Clark's employment contract with General Cleaning provided that the contract could "be transferred to any purchaser of this branch of the business". After General Cleaning sold its assets and transferred Clark's contract to a buyer, Clark worked for the buyer for two weeks (and then for a subsequent buyer for two weeks). The Court held that the jury could find that Clark had not released General Cleaning from its liability to him. (While the instrument of assignment was not before the court, the judgment primarily refers to assignment of "the contract", suggesting that there was a purported assignment of the contract as a whole.) 
The controlling element is the intention of the parties, and unless there is a clear and definite intention on the part of all concerned to extinguish the old obligation by substituting the new [party], then a novation is not effected.

Where the non-assigning party consents to the assignee performing the assignor's obligations or accepts performance from an assignee, the United States case law and commentaries show that this may be: 100

(1) mere approval of the assignee performing the assignor's obligations;

(2) acceptance of an offer to form a novation (which will release the assignor from its obligations); or

(3) acceptance of an offer to enter into a contract with the assignee under which the assignee promises to perform and the non-assigning party to pay, but not a discharge of the contract between the non-assigning party and the assignor.

One qualification is explained in Williston on Contracts as follows: ${ }^{101}$

By whatever name the parties may call the transaction, if it is made clear that the so-called assignor intends by the transaction to be free from all further liability, it seems that acceptance by the other party to the contract of any subsequent performance from the so-called assignee, would amount to assent to a proposed novation, and the so-called assignor would be discharged from further liability.

The assignor will repudiate its contract with the non-assigning party if the nonassigning party does not agree to a proposed novation yet the assignor nevertheless maintains that it is no longer liable to the non-assigning party now that the delegate is (purportedly) liable. ${ }^{102}$

In the absence of evidence to the contrary, United States courts will not find that an assignor who makes an "assignment" intends to propose a novation. ${ }^{103}$

Thus, like New Zealand and English courts, United States courts are generally slow to find that an assignor has shed its obligations to the non-assigning party. In the author's

100 Williston above $\mathrm{n} 12$, s 418.

101 Williston above n 12, s 420 . However, the courts consider the surrounding circumstances in determining whether the non-assigning party has accepted the proposed novation. See for example Epland above $\mathrm{n} 99$ (insured who was notified that the insurer had transferred the policy and would no longer be liable did not necessarily accept a proposed novation by paying premiums to the transferee).

102 Williston above $\mathrm{n} 12$, s 420.

103 Boswell v Lyon (1980) 401 NE 2d 735; Downing v Dial (1981) 426 NE 2d 416. Compare with Barton v Perryman (1979) 577 SW 2d 596. 
view, it is appropriate to protect the non-assigning party's rights in this way, in light of the policy factors set out above in Part II A.

\section{F Conclusions}

New Zealand and English common law has not developed a framework within which to consider purported assignments of obligations (by themselves or as part of a contract). Thus, courts must resort to first principles - or perhaps try to apply Lord Browne-Wilkinson's analysis which correctly reflects legal doctrine but not necessarily commercial practice. In New Zealand, section 11 of the Contractual Remedies Act 1979 adds a further layer of uncertainty. This lack of guiding principles imposes costs on commercial parties seeking to enter into, or understand the consequences of, such transactions.

In contrast, by using presumptions and consequentially applying the third party beneficiaries doctrine, United States courts can, to a greater extent, substitute the assignee in the contractual arrangements, while also preserving the non-assigning party's rights against the assignor. It is submitted that this approach better mirrors parties' intentions in respect of the purported assignment of a contract as a whole.

\section{PROSPECTIVE SUBSTITUTION PROVISIONS}

\section{A Introduction}

As seen above in Part IV, the effect of a purported transfer of contractual obligations is uncertain - especially under New Zealand and English law in comparison with United States law. This Part examines a special case: a purported transfer of obligations pursuant to a provision in the original contract.

Commercial contracts often provide that either or both parties may assign their rights under that contract. Other provisions, which this article will refer to as "prospective substitution provisions", refer more ambiguously to assigning or transferring either "the contract" or both rights and obligations. For example, in New Zealand many utilities' standard form customer contracts state that the utility supplier may transfer the contract to any other person. ${ }^{104}$

104 Of the sample contracts obtained by the author, typical provisions include those stating that the utility can "transfer to someone else all or any part of our side of the agreement", and "transfer to a third party our rights and obligations under this Agreement". 
The primary issue is whether a prospective substitution provision authorises a novation or merely an assignment (perhaps accompanied by a delegation). There are few reported cases on point. ${ }^{105}$ This Part considers, first, prospective substitution provisions requiring consent at the time of transfer, and then provisions with no such consent requirement.

\section{B Prospective Substitution Provisions Requiring Consent}

\section{Novation analysis}

Whether or not the non-transferring party must consent to a proposed transfer pursuant to a prospective substitution provision is important - both legally and commercially.

The granting of consent can support a novation analysis. ${ }^{106}$ In British Gas Trading Limited $v$ Eastern Electricity Plc ${ }^{107}$ British Gas and Eastern Electricity were parties to a long term gas supply contract with the following provision:

Except as provided in General Condition 15(1) above neither party shall transfer or assign its rights or obligations hereunder without the prior written approval of the other party, which approval shall not be unreasonably withheld.

While the issue was whether Eastern Electricity could withhold approval to a proposed transfer by British Gas, Leggatt LJ, delivering the judgment of the English Court of Appeal, noted that:

It seems to me that we are not here concerned with consent to an assignment, properly so

called, but with approval of a novation.

Thus, if given, Eastern Electricity's consent would be construed as accepting an offer to contract with the "transferee" on the same terms as Eastern Electricity's contract with British Gas, and as terminating its contract with British Gas (releasing British Gas from liability for future performance).

105 One reason for this is that such provisions (especially those not requiring consent) are typically found in standard form consumer contracts (such as utility supply contracts) in which case, following a transfer, the transferee usually seeks to establish a new contract between itself and consumers. Therefore the transferor's continuing liability (if any) is rarely in issue. Prospective substitution provisions not requiring consent in contracts between large commercial parties (for example provisions enabling a party to transfer both rights and obligations to another company in the same group) usually provide that the transferor remains liable.

106 However, see above n 69.

107 British Gas Trading Limited v Eastern Electricity Plc (18 December 1996) unreported, Court of Appeal, QBCMF 96/1647/B [British Gas]. 
The New Zealand Court of Appeal's judgment in Commissioner of Inland Revenue $v$ Renouf Corporation Ltd ${ }^{108}$ arguably also supports a novation analysis. ${ }^{109}$ In that case neither party could assign the benefit or burden of a joint venture agreement without the other party's prior consent. The Court stated that: ${ }^{110}$

[The transferor], on the Commissioner's argument, would have ceased to be bound by the joint venture agreement. A novation would have occurred when [the other party] consented to the assignment of [the transferor's] contractual rights. [The transferor] would no longer be bound by its provisions.

A novation analysis would also be consistent with comments of McCarthy $\mathrm{J}$ in $C B$ Peacocke Land Co Limited v Hamilton Milk Producers Co Limited: ${ }^{111}$

A contract which is assignable only by consent is not (unless there is some provision against the unreasonable withholding of consent) in strict language, assignable at all . . .

However, there are other possible analyses.

\section{Assignment of rights only and possible delegation of obligations}

If, as Lord Browne-Wilkinson presumes, lawyers referring to assigning "a contract" know that contractual obligations cannot be assigned, prospective substitution provisions so worded may merely be imprecisely worded standard assignment provisions (that is, for the assignment of contractual rights). The contract as a whole and surrounding circumstances may also show that the parties intend to authorise a delegation of obligations (with or without a subcontract).

Where a provision refers more explicitly to transferring or assigning "obligations" (as in British Gas), ${ }^{112}$ this could be dismissed as based on a mistaken view of the law and hence of no effect, or else interpreted to mean a delegation of obligations. ${ }^{113}$

108 Commissioner of Inland Revenue v Renouf Corporation (1998) 18 NZTC 13,914 [Renouf].

109 The issue in Renouf was whether consideration for the transferor's interest in a joint venture was assessable income. This turned on whether, under the transfer agreement, the transferor transferred the beneficial interest in its shares in the joint venture company as well as its interest in the joint venture agreement. While the Court considered the arrangements as a whole, the effect of the prospective substitution provision was not the central issue. Also, it is not clear from the judgment whether the Court accepted the Commissioner's interpretation of that provision.

110 Renouf above n 108, 13,919.

111 Peacocke above n 97, 581. It is unclear from the context exactly what McCarthy J intended. The author's view is that there is nothing preventing an assignment of rights being subject to the nonassigning party's consent: the consent may be merely a prerequisite to implementing what is otherwise a normal assignment transaction. In some circumstances, a consent may constitute consent to a novation. (See above Part IV E). 
Applying this analysis, rather than a novation analysis, has important consequences. If, following a transfer with consent, the transferor has assigned its rights and merely delegated or subcontracted its obligations it will continue to be responsible for performance under the original contract, so the non-assigning party could sue the assignor for any default in performance but may not be able to sue the delegate. ${ }^{114}$ Also, when consent is sought, the non-transferring party would be free to consent only to the transfer of contractual rights. ${ }^{115}$

\section{Choosing between competing analyses}

It may be difficult to discern the parties' intention in a particular case involving a prospective transfer provision requiring consent. As the consent requirement protects the non-transferring party from a unilateral transfer to a "man of straw", in some cases the parties may have intended that the contract be "transferred" as a whole with the transferor ceasing to be responsible for performance. If so, their intention may be thwarted if the provision and transaction pursuant to that provision are interpreted in light of Lord Browne-Wilkinson's approach instead of an interpretation facilitating rearrangements as far as possible.

As well as the provision itself, the terms of the actual transfer and consent will be important. Even if, on its proper interpretation, a prospective substitution provision enables only the assignment of rights (and perhaps a delegation of obligations), the transfer and consent transaction may nevertheless constitute an agreement to terminate the

112 Although the provision in British Gas above n 107 went further and purported to enable a party not only to "assign" but also to "transfer" its rights and obligations, this does not necessarily assist a transferor as, strictly speaking, a novation does not involve a "transfer" of obligations. See above n 53 .

113 There are obvious parallels with the possible interpretations of s 11(1) of the Contractual Remedies Act 1979, as discussed above in Part II C. The author submits that for most transactions it will be easier to give meaning to inaccurate language used by the parties than that used in $\mathrm{s}$ $11(1)$, as the other parts of the contract and the surrounding circumstances may assist in ascertaining the parties' intention and, in contrast to legislation prepared by a legislative drafter, it should not necessarily be assumed that the parties understand and correctly use technical legal language.

114 Unless any of the bases of liability set out above in Part IV D apply. A contract between the nonassigning party and delegate may come into existence as a result of their dealings with each other.

115 Determining the type of transaction authorised by a prospective substitution provision requiring consent is particularly important where the non-transferring party's ability to withhold consent is constrained (for example where it cannot "unreasonably" withhold consent). In any event, while the non-transferring party might not consent to the transfer of obligations in the sense that the assignor would no longer be responsible for performance, it might not be able to object to the assignor delegating those obligations to the assignee (or any other person). 
original contract and enter into a new contract on the same terms with a new party. Conversely, while a prospective substitution provision may anticipate a novation, a transfer and consent may be merely an assignment of rights (perhaps accompanied by a delegation of obligations). In practice consents are often not worded with the finer nuances of legal doctrine in mind. ${ }^{116}$

In summary, while the particular wording of a prospective substitution provision and corresponding transfer and consent must be carefully examined, it is not clear that such a provision requiring consent will usually result in the "transferee" assuming contractual obligations as well as contractual rights vis-à-vis the non-assigning party and the transferor ceasing to be responsible for performance. Thus, parties wishing to bring about such consequences should ensure that these are clearly specified in the prospective substitution provision and related documents.

\section{Prospective Substitution Provisions Not Requiring Consent}

The position is even less clear when the prospective substitution provision purports to enable assignment or transfer of the contract (or both rights and obligations) without the non-transferring party's consent at the time of the transfer. While the absence of such consent makes it more difficult to apply a novation analysis, the non-transferring party has, in a broader sense, agreed to a transfer - albeit probably to transfers in general rather than a particular transfer, and at the time of the original contact rather than at the time of transfer.

Therefore, do prospective substitution provisions not requiring consent enable what the law generally prohibits, that is, the substitution of one party for another in a contract (and, within that, the substitution of the person liable to perform contractual obligations) by the unilateral action ${ }^{117}$ of one party at the time of substitution? Or should such provisions be interpreted as authorising merely an assignment of rights, perhaps accompanied by a delegation of obligations?

116 In particular, references to "transfer" in the prospective substitution provision and corresponding transfer and consent may suggest - at least to a business person if not a lawyer - that obligations under the original contract are to move from one person to another, rather than be extinguished vis-à-vis the "transferor" and created vis-à-vis the "transferee." See above n 53.

117 The action is unilateral as between the parties to the original contract. The incoming party must consent to enter into a new contract with the non-transferring party before it is contractually bound to the non-transferring party to perform what were previously the transferor's obligations. 
There is some English authority ${ }^{118}$ and Australian dicta ${ }^{119}$ holding that such a provision authorises a novation. On the other hand, there is United States authority holding that a prospective substitution provision does not necessarily constitute prior consent to a novation. ${ }^{120}$

The New Zealand Court of Appeal's decision in Lambly $v$ Silk Pemberton Limited, ${ }^{121}$ concerning a "nominee" provision rather than a prospective substitution provision as such, also shows a reluctance to hold that one party can substitute another person for itself without the other party's consent. In that case, Lambly entered into a contract to sell land to "Nigel Pemberton of Auckland or his nominees". Pemberton later nominated Silk Pemberton Limited as his nominee. When Lambly refused to settle, Silk Pemberton Limited sued Lambly for specific performance. Silk Pemberton Limited argued that the contract gave Pemberton the power to bring about a novation, so that there was continuously a binding contract but one party to it could be altered by unilateral action.

118 In Re European Assurance Society (1875) 1 Ch D 307 (CA) [Re European] an insured had taken out an insurance policy with a life assurance society containing a provision that the policy was subject to the society's deed of settlement. The deed provided that the society could transfer policies to another insurer. The English Court of Appeal held that a transfer pursuant to the deed of settlement was effective to transfer the policy to another insurer so that the society was no longer liable under that policy. The English Court of Appeal has also held that where partnership articles state that any partner may nominate any other person to join the partnership, once a nomination is made and accepted by the nominee the other partners must admit the nominee as a partner: Byrne v Reid [1902] 2 Ch 735 (CA). In The Blankenstein [1985] 1 Lloyd's Rep 93 (CA), where buyers agreed to buy ships themselves and/or on behalf of companies to be nominated by them and later nominated a company, the Court held that there was a novation of the contract in favour of that company as the original contract entitled the buyers to substitute the company. However in The Aktion [1987] 1 Lloyd's Rep 283, Hirst J did not accept that The Blankenstein established "as a matter of principle that the novation must take place at the moment of nomination, whatever the nature and circumstances of the contract" and held in the case before him that the novation did not occur until the seller transferred the ship to the nominee.

119 In Riseda Nominees Pty Ltd v St Vincent's Hospital (Melbourne) Ltd [1998] 2 VR 70, 75 Callaway JA stated that unless the provision in question "conferred a unilateral right on [the party] not only to assign its rights but also to bring about a novation" the transfer of both rights and obligations required a tripartite agreement between both original parties and the transferee. Callaway JA added that in any event "it was more straightforward and made commercial sense to agree that the assignment would be effected by a tripartite agreement".

120 In General Cleaning above $n$ 99, the court held that the jury could find that Clark had not consented in advance to release General Cleaning from its obligations to him.

121 Lambly $v$ Silk Pemberton Limited [1976] 2 NZLR 427 (CA) [Lambly]. Compare with Lang v Fox (10 May 1999) unreported, Court of Appeal, CA49/99 where, following a nomination by a seller which was accepted by the nominee, the buyers accepted the nominee as a contracting party thus creating a novation. 
This was described as "novel", with the judges concluding that: ${ }^{122}$

No doubt it is theoretically possible for a vendor to authorise a purchaser to bring about a substitution of some other person of his own choosing as a new purchaser under the agreement, directly responsible to the vendor as a matter of privity of contract. But the whole concept is so unusual in practice that I would look for much clearer words than are to be found in the present agreement....

[I]n the absence of compelling language I do not think the court should impute to the parties an intention to allow an original signatory to substitute for himself a man of straw ....

The real difficulty in the idea of novation is that novation involves a new contract, to which (it is usually said) the consent of all parties must be obtained.... In the present case the vendor did not in fact consent, and any implied consent which might arguably arise from the contract was withdraw before the nomination of Silk Pemberton Ltd.

[Emphasis added.]

Thus, the Court left open the possibility that, absent a withdrawal of consent, the consent in a sufficiently clear prospective substitution provision may itself be sufficient agreement to a novation at a later time.

There is also dicta in employment contract cases suggesting that a suitably worded prospective substitution provision would enable an employer to substitute a new employer in its place:

[I]n the absence of an express or implied term (and the Court would be very slow to imply one) in the contract of employment or award there is no right to transfer workers to another employer against their will. ${ }^{123}$

It is not possible to transfer the services of an employee from one employer to another . . . unless there be some contractual arrangement which authorises such transfer. ${ }^{124}$

122 Lambly above n 121, 429, 433 and 434. The Court considered that the argument was "not wholly without authority". However, major matters would be left to inference. For example it would have to be implied that, before settlement, the nominee would accept the buyer's obligations under the contract and provide the seller with a sufficient note or memorandum in writing to enable the obligations to be enforced against the nominee.

123 Wellington and Taranaki Shop Employees, etc IUOWv Pacemaker Transport Wellington Limited [1989] 2 NZILR 762, 766 (Labour Court).

124 Wellington etc Local Bodies IUOW v Feilding Borough Council [1983] ACJ 629, 631-632. Also, Attorney-General v Grant [1998] 3 ERNZ 259 (CA) concerned an employment contract providing that the employer could transfer employees. However, the Court of Appeal did not have jurisdiction to determine, and hence left open, the possibility that such a provision could authorise the transfer of employees from one employer to another. 
There is no compelling reason why a suitably worded prospective substitution provision should not enable a party to shed both its rights and obligations where these are assumed by another person. ${ }^{125}$ While this creates some uncertainty over the identity of the parties, a contract will not fail for uncertainty if there is a mechanism to resolve that uncertainty (even if the mechanism is controlled by one party). ${ }^{126}$ The act of substitution by the "transferring" party determines the identity of the new party.

The ability of a party to substitute another person in its place exposes the other party to the risk that a party will substitute a "man of straw". However, contract law does not generally strike down provisions because they create an "unfair" risk. Any such risk could be countered by restrictions on the type of person who could be substituted.

In any event, prospective transfer provisions without a consent requirement may be socially desirable. For example, they promote efficiency by decreasing the transaction costs incurred by a seller of a business transferring that business to a buyer, ${ }^{127}$ and on intra-group transfers of contracts, on a group restructuring. In such circumstances, there may be significant costs in obtaining consent from, or otherwise effecting a novation with, numerous counterparties.

In summary, it seems that prospective substitution provisions that do not require consent at the time of substitution can be effective to enable one party to substitute another person in contractual arrangements (and thus "transfer" contractual obligations as well as contractual rights). However, given the approach proposed by Lord Browne-Wilkinson, and New Zealand courts' reluctance to interpret provisions this way, the provision should set out this intention very clearly. ${ }^{128}$

125 In Re European above $\mathrm{n} 118,322$, the Court emphasised that the issue was resolved by construing the deed of settlement.

126 See for example Coachman Properties Limited v Panmure Video Club Limited [1984] 2 NZLR 200.

127 In Re European above n 118, 317-318 the English Court of Appeal used similar reasoning, noting that:

unless some arrangement of this kind for the transfer of the business of insurance companies is inserted in their deeds of settlement, there is no practical mode by which an insurance company can ever come to an end [but otherwise] must go on for an indefinite period of time, or at all events for the period which will be covered by the aggregate lives of all the parties insured.

128 For an example of a clearly drafted provision see Australian National Airlines above n 69. A buyer of property could nominate another buyer, with the seller having agreed to enter into "an agreement to rescind this contract" and "a contract (with the new purchaser) on the same terms as this contract". However, while the seller was obliged to accept a new party, it had to take action to effect the substitution. Thus, such a provision would not be suitable in, for example, utilities' standard form customer contracts. 


\section{Ancillary Issues}

Substitutions in reliance on a prospective substitution provision may raise issues such as:

(1) Does the transferring party retain (or resume) its obligations when the person sought to be introduced is not able either to enter into the relevant contract or to perform that contract at all (for example, because it does not have a necessary regulatory approval) or the new contract is unenforceable? ${ }^{129}$

(2) Is there a new contract post-substitution or a continuation of the former contract but with a new party? This could be relevant, for example, where the contract contains time limits or renewal provisions.

(3) Where no consent is required at the time of substitution can a party effectively withdraw consent before a substitution occurs? ${ }^{130}$

Where such uncertainties are significant to a party, they could be removed or minimised, for example by setting out in the original contract the parties' intention regarding the prospective substitution provision.

\section{PRACTICAL DRAFTING SUGGESTIONS}

The earlier Parts of this article have shown that the law on "assignment" or "transfer" of contractual obligations is uncertain in some respects. The application of the law is also uncertain, as it depends on discerning the parties' intention (or, perhaps more realistically, imputing an intention to them) in the absence of a developed interpretive framework such as that used by United States courts.

129 By analogy, in Morris $v$ Baron [1918] AC 1, where parties to a written contract for sale of goods substituted an oral contract, the House of Lords held that even though the new contract was not enforceable (as it was not in writing as required by statute) the former contract had been terminated and hence could no longer be relied upon. See also United Dominions Corporation (Jamaica) Ltd $v$ Shoucair [1969] 1 AC 340 (PC) (although variation unenforceable, no intention to terminate original contract so this remained in force).

130 This happened in Lambly above n 121, 434, with Cooke J stating that vis-à-vis the nominee, the seller could withdraw consent as she was not in a contractual relationship with the nominee. As the party seeking to exit the contract was not a party to proceedings, the Court did not examine the effect vis-à-vis that party. Thus, a party seeking to exit in reliance on a prospective substitution provision may be able to enforce that provision in the face of a purported withdrawal of consent - and, if s 4 of the Contracts (Privity) Act 1982 applies, the proposed incoming party may also be able to do so. See also Re European above n 118, 319 (even if the applicant had refused to submit to the transfer of the society's business, his refusal would have been in vain) and Bailey above $\mathrm{n} 67,217-218$ (prior consent given in a contract binds the party giving consent). 
The author submits that the law should be clarified to minimise this uncertainty, and thus to lower the costs that such uncertainty creates in commercial transactions. Absent such clarification, parties to commercial contracts can minimise uncertainty themselves by drafting assignment and prospective substitution provisions and related documents ${ }^{131}$ to correctly reflect the underlying legal principles and, in light of those principles, to state the parties' intention as clearly as possible. Various suggestions are set out below.

\section{A Assignors}

(1) Do not refer in assignment provisions in contracts (and in related documents) to "assigning" a contract as a whole (or to "assigning" both rights and obligations), but instead to assigning rights and, if relevant, delegating or subcontracting obligations.

(2) Consider whether the original contract should prevent the non-assigning party enforcing the remedies of damages and cancellation against an assignee.

(3) If the assignee is to perform the assignor's obligations, make clear in dealings with the assignee whether the assignee is merely authorised to do so ${ }^{132}$ or is contractually bound to the assignor to do so. ${ }^{133}$

(4) If the assignee is to be contractually bound to the assignor to perform the obligations, consider whether the contract with the assignee should specify a remedy for failure to perform (which may be, or include, the assignee indemnifying the assignor for any liability of the assignor to the non-assigning party as a result of any default by the assignee).

(5) To avoid liability following a transfer (for example where there is to be a novation), make this intention clear to the non-assigning party and obtain its consent.

\section{B Assignees}

(1) If involved at the time the original contract is negotiated, consider whether to promote a provision excluding the enforceability of the remedies of cancellation and damages against the assignee.

131 For example agreements or notices containing assignments, notices to non-assigning parties, and consents to assignments or substitutions. Sometimes there may be tactical reasons why a party does not wish to make the consequences of a transaction clear.

132 This may be appropriate when the assignor is assigning all its rights under the contract and is not concerned about whether the contract is performed.

133 This may be appropriate when the assignor will be liable to the non-assigning party in the absence of performance, rather than the assignee merely lose the ability to enforce rights against the nonassigning party. 
(2) When taking rights, check the original contract to determine whether these depend on the performance of obligations (and, if so, clarify with the assignor who is to perform those obligations), whether the non-assigning party is excluded from enforcing damages or cancellation against the assignee, and whether the limitation on the assignee's liability in section 11(2) of the Contractual Remedies Act 1979 is excluded.

(3) To take rights free of some or all conditions (or other equities), enter into an agreement with the non-assigning party to this effect.

(4) If expressly or impliedly assuming all or some of the assignor's obligations, ensure that those obligations, and whether or not the assignee is contractually bound to the assignor to perform those obligations, is clear.

(5) Before becoming contractually bound to the assignor to perform those obligations, consider whether the contract with the assignor should exclude the non-assigning party being able to bring proceedings against the assignee by relying on the Contracts (Privity) Act 1982.

\section{Non-Assigning Party}

(1) As well as ensuring that any assignment provision in the original contract (and related documents if the non-assigning party is a party to these) is worded in accordance with the underlying legal principles, ensure that (if intended) that provision makes clear that the assignor's liability continues after any assignment or transfer.

(2) When negotiating the original contract, check for any limitation on exercising remedies against the assignee, and consider whether to exclude the limitation on the assignee's liability under section 11(2) of the Contractual Remedies Act 1979.

(3) To be sure of a right of action against the assignee for default in performing the assignor's obligations, contract directly with the assignee, have the assignee enter into a deed in the non-assigning party's favour binding the assignee to performance, or ensure that section 4 of the Contracts (Privity) Act 1982 can be relied upon.

\section{Prospective Substitution Provisions}

(1) Make clear whether or not the transferring party will continue to be liable for any default in performance. 
(3) Consider whether the prospective substitution provision should specify any other consequences of a substitution. ${ }^{134}$ For example, should it state that the new contract between the non-transferring party and the new party will be deemed for the purposes of time periods specified in the contract to have been entered into at the time of the original contract?

(4) When seeking and granting consent to a proposed transaction pursuant to an ambiguous prospective substitution provision, make clear whether the consent is to an assignment of rights, a substitution (that is, novation) or other transaction.

(5) The non-transferring party should ensure that the new party is contractually bound to it.

\section{CONCLUSION}

The law on the "assignment" or "transfer" of contractual obligations in New Zealand is unclear. As well as the uncertainties that arise at common law, New Zealand lawyers and courts must contend with the confusion created by section 11 of the Contractual Remedies Act 1979. Despite having been on the statute books for 20 years, the courts have not clarified its meaning. This creates difficulties for lawyers in structuring transfers and in determining the consequences of past transfers.

Thus, an authoritative clarification of section 11 by the courts or by legislative amendment would be welcomed. However, even more might need to be done. While contract law has to some extent moved from treating contracts as creating only personal rights and obligations, it may need to move even further to be appropriate for the market characteristics of the 21st century. As has been stated of the development of the United States law in this area: ${ }^{135}$

There is no doubt that the American rule on assignment and delegation ... stands the doctrine of privity on its head. Free assignability and the concomitant presumption of a delegation of duties, however, have been extraordinarily useful in the development of a credit economy and in the free alienation of property in a dynamic, fluid economy.

The United States case law suggests other mechanisms which, if adopted in New Zealand, could move theory closer to practice.

In the meantime, the inconclusive nature of the theory surrounding the "assignment" or "transfer" of contractual obligations means that, in practice, the burden falls on lawyers to

134 This is especially important when a substitution can be made without consent or there are limited grounds for withholding consent, as the non-transferring party may not be able to withhold consent until uncertainties are clarified.

135 Hunter, above n 79, 54 
draft documents that clearly indicate the nature and effect of any such transfer or assignment.

DU TRANSFERT À UN TIERS DES OBLIGATIONS CONTRACTUELLES : LA NÉCESSAIRE CONCILIATION DE LA PRATIQUE ET DE LA THÉORIE

Si l'on s'accorde d'une manière générale, dans la Common Law, à reconnaître que les droits issus de relations contractuelles peuvent être transmissibles à des tiers, le doute et l'incertitude demeurent encore quant à la possible transmission des obligations contractuelles.

L'auteur, à la lumière des dispositions de l'article 11 du Contractual Remedies Act 1979 et des méthodes de transfert des obligations retenues par la pratique, examine et compare leur mise en œuvre dans le droit positif néo-zélandais, anglais et nord américain.

Elle démontre ainsi, la nécessité qu'il peut y avoir de clarifier certains des principes dégagés par la Common Law dans ce domaine, proposant pour ce faire, quelques solutions pratiques pour que puisse être, notamment, prise en compte l'intention des parties et ce d'autant plus que le droit positif reste encore incertain. 
